\author{
Anna SzydŁowska, AleKsandra Kurzyńska, ZuZanna KunickA, IwONA BogackA
}

\author{
Katedra Anatomii i Fizjologii Zwierzat \\ Wydzial Biologii i Biotechnologii \\ Uniwersytet Warmińsko-Mazurski w Olsztynie \\ Oczapowskiego 1A, 10-718 Olsztyn \\ E-mail: iwonab@uwm.edu.pl
}

\title{
RECEPTORY AKTYWOWANE PRZEZ PROLIFERATORY PEROKSYSOMÓW W PROCESIE NOWOTWORZENIA - FAKTY I KONTROWERSJE
}

\section{WSTEP}

Receptory aktywowane przez proliferatory peroksysomów (PPAR) należą do rodziny steroidowych receptorów jądrowych (ISSEMAN i GreEn 1990). Pełnia funkcję ligando-zależnych czynników transkrypcyjnych, które zaangażowane sa przede wszystkim w utrzymanie energetycznej homeostazy organizmu. Biora udział w regulacji ekspresji genów zwiazanych z metabolizmem glukozy i lipidów. Ich rolę podkreślano także w regulacji procesów rozrodczych (BoGACKA i współaut. 2015). Dotychczas zidentyfikowano trzy izoformy PPAR: $a, \beta / \delta$ i $\gamma$. Należy uwzględnić także trzy rodzaje izoformy gamma: $\gamma 1, \gamma 2$ i $\gamma 3$, które powstaja w wyniku alternatywnego składania genu kodujacego tę izoformę (FAJAS i współaut. 1997). Wymienione, podstawowe formy PPAR wykazują duży stopień pokrewieństwa, jednak różnią się aktywnościa, rodzajem ligandów, odmienną specyficznością tkankowa, pełnią różne funkcje i kodowane sa przez oddzielne geny, które u człowieka zlokalizowane sa na chromosomach, odpowiednio na 3., 6. i 22. Charakteryzuja się typowa budowa domenowa, jaka ma grupa receptorów jądrowych, a podstawowe jednostki: A/B, C, D, E/F, kodowane sa przez gen składający się z 6 eksonów.

W wyniku zwiazania się liganda $z$ receptorem PPAR nie dochodzi do pełnej jego aktywacji. Istotnym etapem jest utworzenie dimeru $z$ receptorem kwasu retinowego RXR. Powstały heterodimer ma zdolność do łączenia się $z$ odpowiednią sekwencja DNA, znajdujaca się wewnattrz promotora regulo- wanego genu, tzw. elementem odpowiedzi na PPAR (PPRE). Fragment ten zbudowany jest z 13 nukleotydów: 2 sześcio-nukleotydowych sekwencji AGGTCA, które oddzielone sa pojedynczym, dowolnym nukleotydem (WILLSON i współaut. 2000). Wynikiem połączenia $\operatorname{PPAR} z$ promotorem określonego genu jest zainicjowanie zmian w jego ekspresji. Do tej pory opisano wiele zwiazków, zdolnych do wiazania się $z$ PPAR. Naturalnymi ligandami, które do tej pory zostały najlepiej poznane, sa kwasy tłuszczowe. Do tych o największym powinowactwie należą kwasy: linolenowy, linolowy oraz arachidonowy, aktywujace receptory w stężeniach mikromolarnych (KREY i współaut. 1997). Endogennymi ligandami PPAR moga być również niektóre prostaglandyny, będace pochodnymi kwasu arachidonowego oraz utlenione fosfolipidy.

Ligandy egzogenne, w większości przypadków, maja farmakologiczne właściwości i znajduja zastosowanie w leczeniu chorób metabolicznych. Największą swoistością wobec PPARa charakteryzuja się fibraty (FoRMAN i współaut. 1997). Należą do nich takie zwiąki jak: bezafibrat, gemfibrozil, fenofibrat i klofibrat, które znajduja zastosowanie w leczeniu zaburzeń lipidowych; redukuja koncentrację triglicerydów we krwi i zwiększaja poziom „dobrego" cholesterolu (ang. high-density lipoprotein, HDL) (ScHOOJANS i współaut. 1995).

Kolejna, bardzo ważną grupa substancji syntetycznych sa tiazolidinediony (TZD), zaliczane do agonistów PPARy. Wśród tej grupy na szczególną uwagę zasługują: roziglitazon, troglitazon, ciglitazon i pioglitazon; niektóre $z$ 
nich sa stosowane farmakologicznie (zwłaszcza pioglitazon), bowiem prowadza m.in. do zmniejszenia insulinooporności u osób $z$ cukrzyca typu 2 (DAY 1999). Substancje te sa również wykorzystywane w leczeniu syndromu policystycznych jajników (PCOS). Ponadto stwierdzono, że ligandami dla PPARy (posiadajacymi też zdolność do aktywacji PPARa) moga być także niesteroidowe leki przeciwzapalne (NLPZ), które wykazują plejotropowe działanie na ludzki organizm. Substancjami takimi są: indometacyna, fenoprofen, ibuprofen i kwas flufenamowy. Istnieja również inne ligandy dla PPARy, które różnią się właściwościami i budowa, np. CDDO (kwas 2-cyjano-3-12-diokso-oleano-1,9-dien28-owy), GW-7845 (MrÓWKA i GŁODKOWSKA-MRÓWKA 2011), czy substancje stworzone na bazie kwasu fenylooctowego (CHITTIBOYINA i współaut. 2006).

Rola PPAR $\beta / \delta$ w organizmie człowieka została poznana najsłabiej i najpóźniej. Dotyczy to również określenia specyficznych ligandów dla tego receptora. Dopiero w 2001 r. otrzymano substancję wykazująca wysoka selektywność względem PPARß/ठ (OLIVER i współaut. 2001). Substancje aktywujace PPAR $\beta / \delta$ to między innymi: GW-501516, L-165041 i NLPZ.

Wiele wyników badań wskazuje, że PPAR sa zaangażowane $\mathrm{w}$ powstawanie reakcji zapalnej oraz modulowanie proliferacji i różnicowania komórek (PETERs i współaut. 2012), co sugeruje, że moga one uczestniczyć w regulacji wzrostu komórek nowotworowych. Potwierdzeniem tej tezy może być fakt, że w wielu komórkach, w których zaszły zmiany nowotworowe, zaobserwowano obecność genu i białka różnych izoform PPAR. Jak się okazuje, wszystkie izoformy maja związek $z$ procesem nowotworzenia, ale każda $z$ nich pełni nieco inna funkcję w rozwoju poszczególnych rodzajów nowotworów. Poniżej przedstawiono istniejace poglądy i kontrowersje na temat udziału poszczególnych izoform PPAR w procesie nowotworzenia.

\section{PPARa}

Już od momentu wykrycia PPARa w wątrobie myszy sugerowano, że zwiększona proliferacja peroksysomów, spowodowana przez ligandy PPAR $z$ grupy ksenobiotyków, może mieć fatalne skutki w tej tkance. Istotnie, wyniki wielu badań wskazuja, że długotrwała aktywacja PPARa może skutkować rozwojem nowotworu wątrobowokomórkowego u gryzoni. Molekularny kancerogenny mechanizm aktywacji PPARa zależnej od fibratów został dosyć dobrze poznany u gryzoni (MISRA i REDDY 2014) i obejmuje hipertrofię i hiperplazję wątroby, gwałtowny wzrost proliferacji peroksysomów, a także zwiększenie ekspresji genów kodujacych enzymy zaangażowane w metabolizm kwasów tłuszczowych w różnych organellach komór-

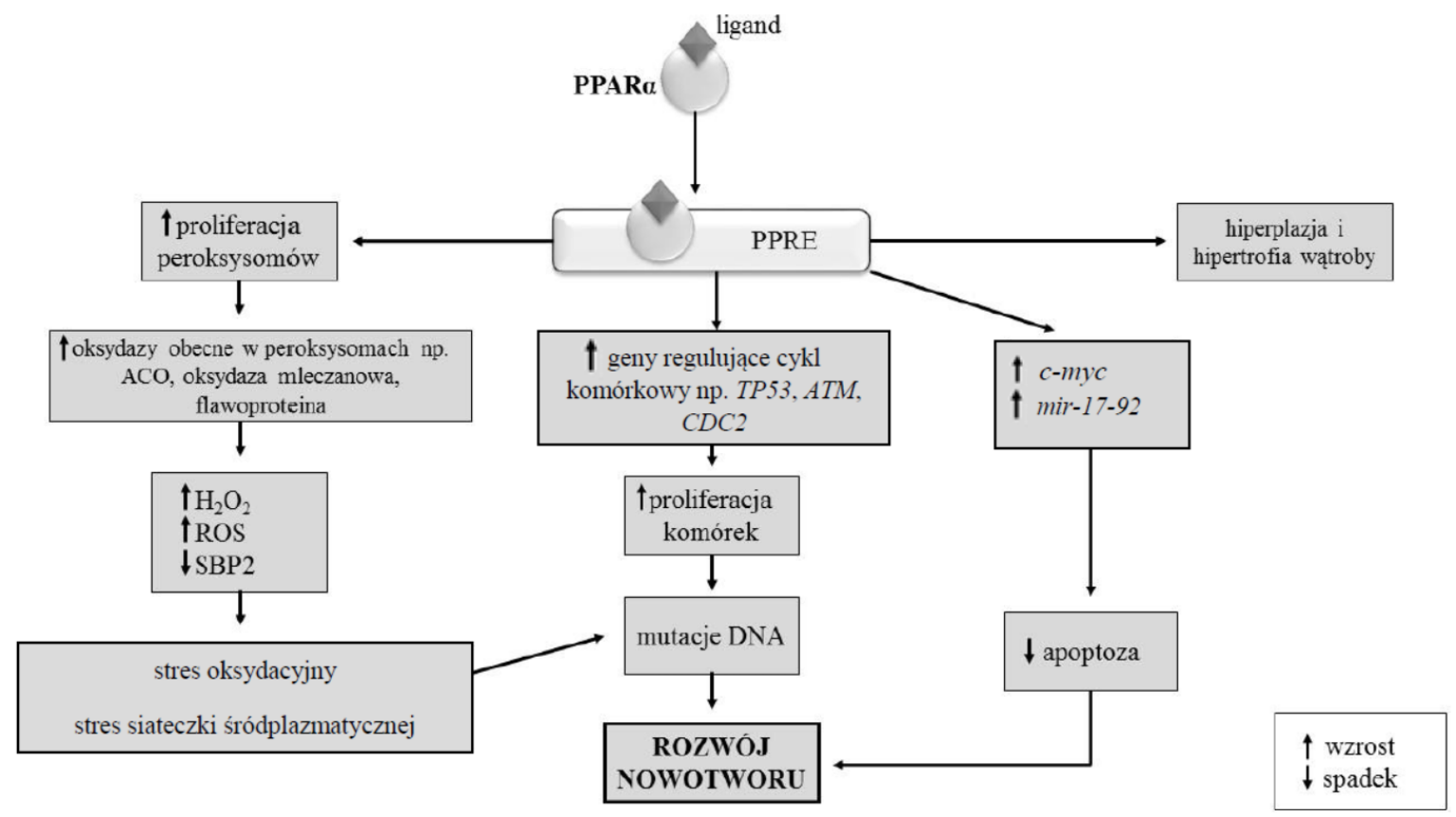

Ryc. 1. Schemat przedstawiajacy kancerogenne efekty aktywacji PPARa.

$A C O$ - oksydaza acetylo-CoA, ATM - gen kodujący kinaze ATM, CDC2 - gen kodujący kinazę CDK1, c-myc - onkogen, mir-17-92 - onkogen, ROS - reaktywne formy tlenu, SBP2 - białko wiażace selen, TP53 - gen kodujący białko p53, PPRE - element odpowiedzi na proliferatory peroksysomów. 
kowych (mitochondria, peroksysomy, siateczka śródplazmatyczna). Enzymy te odpowiedzialne sa za zwiększone zużycie energii oraz za generowanie w komórkach dużych ilości nadtlenku wodoru $\left(\mathrm{H}_{2} \mathrm{O}_{2}\right)$ i innych reaktywnych form tlenu (ROS). Towarzyszy temu wielokrotna redukcja ekspresji białka anty-kancerogennego SBP2 (ang. selenium binding protein 2), uczestniczacego w hamowaniu wzrostu guza (GIOMETTI i współaut. 2000) oraz wzrost poziomu 8-hydroksydeoksyguanozyny, markera stresu oksydacyjnego (KASAI i współaut. 1989). Długotrwały stres oksydacyjny prowadzi z kolei do uszkodzeń DNA, które stanowią jeden $z$ pierwszych etapów procesu nowotworzenia. Należy uwzględnić również wpływ ligandów PPARa i nasilonego stresu oksydacyjnego na ekspresję genów zaangażowanych w regulację cyklu komórkowego. Obecnie sądzi się, że proliferacja komórek zaburzona przez uszkodzenia DNA wywołane stresem oksydacyjnym, może być jednym $z$ ważniejszych elementów odpowiedzialnych za transformacje nowotworowa w watrobie, spowodowana aktywacja PPARa. Schemat ilustrujacy możliwy udział PPARa w procesie kancerogenezy zaprezentowano na Ryc. 1.

Wyniki badań wskazują, że długotrwała aktywacja PPARa w watrobie myszy indukuje ekspresję onkogenu mir-17-92, a także onkogenu c-myc, częściowo poprzez hamowanie ekspresji let-7CmiRNA, który kontroluje poziom białka c-myc poprzez destabilizację jego mRNA (SHAH i współaut. 2007). Jednak brak wpływu aktywatorów PPARa na ekspresje genu let-7c, a także brak proliferacji komórek i guzów nowotworowych zanotowano w watrobie "humanizowanych" myszy, które posiadały ludzki gen PPARa (YANG i współaut. 2011). Sugeruje to gatunkowo-zależna regulację genu $c$-myc, a także gatunkowo-zależne predyspozycje do rozwoju nowotworu w watrobie.

U myszy traktowanych dużymi stężeniami Wy-14,643 (syntetyczny aktywator PPARa) zaobserwowano wzrost replikacji DNA w hepatocytach oraz rozwój pierwotnych guzów w tkance u wszystkich badanych osobników (PETERS i współaut. 1997). Z kolei taka zależność nie występuje w watrobie gryzoni pozbawionych receptora PPARa (PETERS i współaut. 1997), a podawanie fibratów nie prowadzi do rozwoju nowotworu w tej tkance (HAYs i współaut. 2005). Podobnie, długotrwałe podawanie fibratów nie wywołuje zmian nowotworowych w wątrobie ludzkiej. Należy podkreślić, że brak zależności pomiędzy PPARa a rozwojem nowotworu w watrobie człowieka jest bardzo istotna kwestia, ponieważ stosowanie agonistów tych receptorów jest praktykowane w leczeniu pacjentów $Z$ zaburzonym profilem lipidowym od kilkudziesięciu lat. Ponadto, powszechnie stosowane ftalanowo-estrowe plastyfikatory, przemysłowe rozpuszczalniki czy herbicydy, aktywujace PPARa, moga także stanowić potencjalne zagrożenie dla człowieka. Jednak badania epidemiologiczne nie wykazały wzrostu proliferacji peroksysomów w watrobie pacjentów leczonych za pomoca preparatów hipolipemicznych. Funkcjonalne różnice $\mathrm{w}$ odpowiedzi na podawanie agonistów PPARa, pomiędzy gatunkami gryzoni i ludzi, nie sa do końca oczywiste, chociaż logicznym wytłumaczeniem może być znacznie niższy poziom ekspresji PPARa w wątrobie ludzkiej niż gryzoni. Ludzkie hepatocyty posiadaja jedynie $1-10 \%$ ilości tych receptorów występujacych u gryzoni (PALMER i współaut. 1998) i to prawdopodobnie chroni tkankę przed rozwojem nowotworu.

Pomimo że aktywacja PPARa przez syntetyczne ligandy nie jest toksyczna dla ludzkiej watroby, to jednak nasuwa się pytanie, czy jest bezpieczna dla innych tkanek, które charakteryzują się dużą ekspresją tych receptorów. Wyniki badań prowadzonych przez SALVO i współaut. (2014) sugerują, że istnieje istotna zależność pomiędzy dawką fibratów (>550 DDD, dawka dobowa definiowana) a zwiększonym ryzykiem rozwoju nowotworu (raka skóry i peccherza moczowego) w tkankach o wysokiej ekspresji PPARa. W przeciwieństwie do powyższych badań, GARDETTE i współaut. (2009) wskazują, że długotrwałe podawanie leków hipolipemicznych (włączajac fibraty) francuskim pacjentom istotnie zmniejszyło ryzyko śmierci $z$ powodu nowotworu. Istnieją również dane wskazujace na możliwy chemoprewencyjny efekt gemfibrozilu na rozwój czerniaka, chociaż sa również dane nie potwierdzajace tej teorii (FREEMAN i współaut. 2006).

Przeciwnowotworowe działanie syntetycznych ligandów PPARa wskazywano także w badaniach prowadzonych w warunkach in vitro. Wykazano np. hamujace działanie kwasu klofibrowego na proliferację komórek uzyskanych $z$ ludzkich nowotworów jajnika (linie komórkowe OVCAR-3 i DISS) (YOKOYAMA i współaut. 2007). Ponadto, syntetyczne ligandy PPARa (fenofibrat lub gemfibrozil) indukowały apoptozę i spowalniały proliferację w nowotworowych komórkach błony śluzowej macicy (linia komórkowa Ishikawa) (SAIDI i współaut. 2006), piersi, okrężnicy (YOUSEFI i współaut. 2016) oraz w komórkach glejaka (STRAKOVA i współaut. 2005). Wyniki badań sugeruja, że przeciwnowotworowy efekt działania fibratów polega na ich zdolności do hamowania aktywności kompleksów mitochondrialnych, czego wynikiem jest upośledzenie działania łańcucha oddechowego. 
Wywołany $\mathrm{w}$ ten sposób stres oksydacyjny pobudza komórki nowotworu do różnicowania i dojrzewania, w efekcie zmniejszając ich zdolność do proliferacji (YoUSEFI i współaut. 2016).

Poza potencjalnym wykorzystaniem aktywatorów PPARa jako narzędzia do terapii skierowanej przeciwko nowotworzeniu, warto zwrócić uwage na pozytywne w skutkach hamowanie aktywności receptora w dwóch dotychczas opisanych typach nowotworów. BENEDETTI i współaut. (2016) uzyskali obiecujace wyniki podczas badań nad nowotworem mózgu $z$ wykorzystaniem AA452, antagonisty PPARa. Ligand ten blokując receptor przyczynił się do indukowania apoptozy w komórkach nowotworowych, zwiększenia ich podatności na działanie radioterapii i zmniejszenie migracji komórek. Zastosowanie innego antagonisty, GW6471, zwiększyło oksydację kwasów tłuszczowych i przyczyniło się do hamowania glikolizy w linii komórkowej raka nerek (ABU ABOUD i współaut. 2015).

\section{$\mathrm{PPAR} \beta / \delta$}

Wielu badaczy wskazuje na udział PPAR $\beta / \delta \mathrm{w}$ procesie nowotworzenia, chociaż dostępne doniesienia na ten temat sa raczej mało spójne (MÜLLER 2016). Sprzeczności

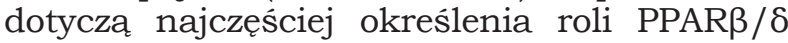
w rozwoju raka jelita grubego (RJG) w przebiegu zespołu rodzinnej polipowatości gruczolakowatej (FAP). RJG jest pierwszym rodzajem nowotworu, w którym zauważono istotna rolę PPAR $\beta / \delta$. Obecnie brane sa pod uwage dwa mechanizmy aktywacji PPAR $\beta / \delta$ $\mathrm{w}$ omawianym procesie, zarówno pro-, jak i anty-kancerogenny. Część przeprowadzonych badań wskazuje, że zwiększona ekspresja mRNA dla PPAR $\beta / \delta$ stymuluje rozwój nowotworu poprzez zwiększenie proliferacji komórek i hamowanie apoptozy (Ryc. 2). Istotnie większa koncentrację mRNA dla PPAR $\beta / \delta$ stwierdzono w tkance nowotworowej jelita grubego (GUPTA i współaut. 2000). Już ponad 15 lat temu za ważny mechanizm procesu kancerogenezy $w$ jelicie grubym uznano zależność pomiędzy ekspresja omawianego receptora a aktywacja szlaku APC (białko gruczolakowatego polipa okrężnicy)/ $\beta$-katenina/TCF-4 (czynnik transkrypcyjny komórek T) (HE i współaut. 1999). Wykazano wówczas, że mutacja genu $A P C$, występujaca w zespole chorobowym FAP, utrudnia ubikwitynacje i degradację powstajacego kompleksu APC- $\beta$-kateniny i auksyny. W zwiazku $z$ tym, wzrost akumulacji $\beta$-kateniny w komórce przyczynia się do jej translokacji do jacdra i tworzenia kompleksu z czynnikiem transkrypcyjnym TCF-4. Czyn- nik ten aktywuje PPAR $\beta / \delta$, a także zwiększa transkrypcję genów zaangażowanych w proliferację komórek takich jak: c-myc i cykliny D (PETERs i współaut. 2015). Zjawisko to ulega szczególnemu nasileniu, jeżeli komórki posiadaja mutacje w genie KRAS (BIERI i współaut. 1984), który jest protoonkogenem bioracym udział w powstawaniu raka jelita grubego, płuca, jajnika i innych nowotworów. Niedawno wykazano, na podstawie bardziej zaawansowanych badań, $\mathrm{m}$. in. $z$ użyciem mikromacierzy, że aktywacja wewnattrzkomórkowego szlaku sygnalizacyjnego APC/ $\beta$-katenina/TCF-4 nie jest odpowiedzialna za zmiany w ekspresji mRNA dla PPAR $\beta / \delta$ (PETERS i współaut. 2012). Podobne sprzeczności dotycza korelacji pomiędzy aktywnościa PPAR $\beta / \delta$ a wewnatrzkomórkowym szlakiem sygnalizacyjnym PTEN/PI3K/ Akt, uczestniczacym w regulacji procesu apoptozy. Dostępne dane wskazuja, że ligando-zależna aktywacja PPAR $\beta / \delta$ zwiększa ekspresję mRNA PDK1/ILK oraz obniża ekspresję mRNA PTEN, prowadzacc do zwiększonej fosforylacji AKT i w konsekwencji hamowania apoptozy i zwiększenia szans przeżycia komórki. Sa jednak dostępne również wyniki badań niepopierające tej obserwacji. Wskazuja one, że aktywacja PPAR $\beta / \delta$ tłumi ekspresję mRNA PDK1, ILK i fosforylację AKT (PETERS i współaut. 2015).

Interesujace wydaja się wyniki ostatnich badań retrospektywnych (duża liczba pacjentów i wieloletnie badania), które wskazuja na protekcyjne działanie zwiększonej aktywności PPAR $\beta / \delta$. Podwyższona ekspresja mRNA dla PPAR $\beta / \delta$ w guzach pierwotnych jest zwiazana $z$ obniżona ekspresja mRNA Ki-67 (markera proliferacji). Ponadto, występuje ona $z$ większą częstotliwością w przypadkach nowotworów w pierwszej fazie rozwoju, natomiast $z$ mniejsza $w$ jego późniejszych fazach, właczajac $w$ to faze metastazy w węzłach chłonnych (YANG i współaut. 2011). Dodatkowo stwierdzono, że ekspresja mRNA dla PPAR $\beta / \delta$ w guzach pierwotnych bywa zróżnicowana i to co istotne, ryzyko śmierci pacjentów jest prawie 4-krotnie zmniejszone w przypadku wysokiej ekspresji tego genu w guzach nowotworowych jelita grubego (YANG i współaut. 2011), w porównaniu $z$ pacjentami, $u$ których stwierdzono jego niska ekspresję w tkance. Dostępne sa również i takie wyniki badań które wykazują, że możliwości przeżycia pacjentów z RJG wyraźnie malały, kiedy w tkance nowotworowej wykazywano wspólną ekspresję mRNA zarówno PPAR $\beta / \delta$, jak i cyklooksygenzay 2 (COX-2) (YoshinAGA i współaut. 2009), enzymu katalizujacego reakcję przemiany kwasu arachidonowego, w porównaniu $z$ tymi pacjentami, u których nie wykazywano ta- 


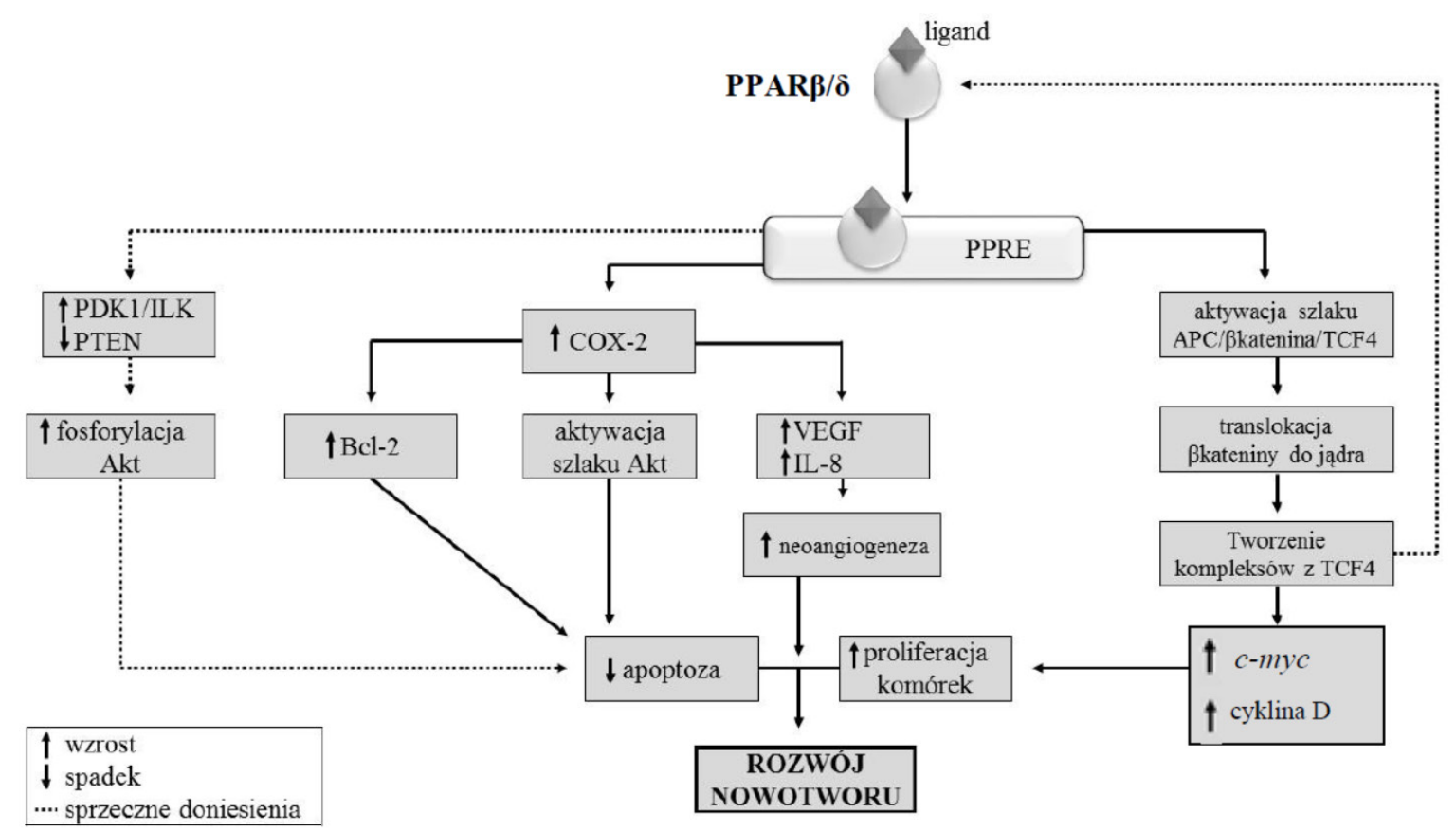

Ryc. 2. Schemat przedstawiajacy kancerogenne efekty aktywacji PPAR $\beta / \delta$.

APC - białko gruczolakowatego polipa okrężnicy, Bcl-2 - białko antyapoptyczne, c-myc - onkogen, COX-2 - cyklooksygenaza 2, IL-8 - interleukina 8, ILK - kinaza związana z integrynami, PDK1 - kinaza 1 zależna od fosfatydyloinozytolu, PTEN - fosfataza fosfatydyloinozytolo-3,4,5-trifosforanu, TCF4 - czynnik transkrypcyjny komórek T, VEGF - czynnik wzrostu śródbłonka naczyniowego, PPRE - element odpowiedzi na proliferatory peroksysomów.

kiej wysokiej ko-ekspresji obu białek. Sugeruje się zatem, że zwiększona ekspresja

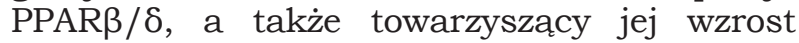
ekspresji mRNA dla COX-2, powoduja rozwój RJG i nie jest to wskaźnikiem rokującym przeżycie pacjentów. Należałoby dodać, że ekspresja mRNACOX-2 jest zazwyczaj niska w większości tkanek, natomiast w wyniku działania cytokin prozapalnych następuje gwałtowny i szybki wzrost jej aktywności (TACHIBANA i współaut. 2008). COX-2 mody-

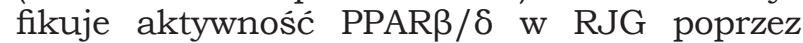
regulację syntezy prostaglandyn: $\mathrm{PGI}_{2}$ lub $\mathrm{PGE}_{2}$ (GuPTA i współaut. 2000). Wysoką ekspresję COX-2 obserwowano $\mathrm{w}$ wielu rodzajach nowotworu: jelita grubego, płuc, trzustki, endometrium oraz piersi (HIDA i współaut. 1998, CHAN i współaut. 1999, TUCKER i współaut. 1999, SosLOw i współaut. 2000, HASEGAWA i współaut. 2005). Udowodniono, że niesteroidowe leki przeciwzapalne (NLPZ), które aktywuja PPAR $\beta / \delta$, ale jednocześnie hamuja aktywność COX-2, indukowały proces apoptozy w komórkach raka jelita grubego, hamujac tym samym proces kancerogenezy (SHUREIQI i współaut. 2003). Istnieja dowody, że podawanie chorym $z$ zespołem FAP niesteroidowych leków przeciwzapalnych zmniejszało u nich ryzyko wystapienia raka jelita grubego nawet o 40-50\% (GUPTA i DUBoIs 2001). W swietle tych doniesień NLPZ moga znaleźć zastosowanie jako skuteczniejsze środki lecznicze i zapobiegajace rozwojowi raka jelita grubego.

Pomimo wielu doniesień o przeciwnowotworowej roli PPAR $\beta / \delta$ sa i takie, które świadczą o roli kancerogennej. Wykazano

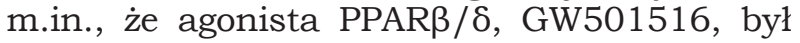
czynnikiem stymulującym rozwój raka sutka u myszy. Dostępne są również wyniki badań wskazujące na zahamowanie wzrostu ludzkiej linii komórkowej nowotworu sutka (MCF7), a także linii komórkowej ludzkiego czerniaka skóry w obecności agonistów: GW0742 i GW501516 (UACC903) (TACHIBANA i współaut. 2008). Z kolei, w badaniach WU i współaut. (2016) chemioterapeutyk telmisartan powodował obniżenie przeżywalności komórek nowotworowych prostaty, jednak efekt ten był znoszony w obecności antagonisty PPARß/S (GSK0660) lub przy zastosowaniu komórek $z$ wyciszonym genem kodujacym ten receptor. Badania te podkreślaja znaczenie szlaku sygnalizacyjnego zwiazanego $z$ PPAR $\beta / \delta$ w przyszłych badaniach nad leczeniem raka prostaty, ale być może i innych rodzajów nowotworów.

Możliwym wyjaśnieniem sprzeczności występujących w literaturze może być fakt, że aktywacja PPAR $\beta / \delta$ jest zwiazana $z$ rodzajem stosowanych $\mathrm{w}$ badaniach ligandów. $\mathrm{Z}$ tego punktu widzenia sprzeczne wyniki ba- 
dań moga wynikać $z$ różnic w warunkach hodowli komórek lub z różnego tła genetycznego modeli zwierzęcych (TACHIBANA i współaut. 2008). Należy wziąć również pod uwage fakt, że przyczyna otrzymywania sprzecznych wyników może być sposób przeprowadzanych badań. Zazwyczaj mierzona jest jedynie ekspresja mRNA, nie zaś synteza białka. Częsty jest również brak negatywnych i pozytywnych kontroli, a liczba badanych próbek jest zbyt mała. Analiza ekspresji białka przeprowadzana jest często za pomoca metod immunohistochemicznych. Stosowanie wyłacznie takiej metody analizy jest szczególnie problematyczne, ponieważ niespecyficzna immunoreaktywność wiązania $z$ prze-

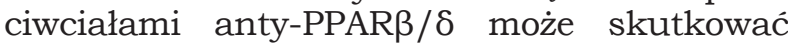
otrzymywaniem fałszywie pozytywnych wyników (PETERs i współaut. 2012). Szczegółowe zrozumienie tych zawiłości może okazać się bardzo przydatne podczas szukania nowych metod leczenia i zapobiegania chorobom nowotworowym.

\section{PPARY}

Rola PPARy w procesie nowotworzenia jest najbardziej złożona i najczęściej badana. Liczne badania wykazały obecność tej izoformy w różnych typach komórek zmienionych nowotworowo. Zwiększona ekspresję zaobserwowano w komórkach raka jelita grubego, piersi, wątroby, przełyku, żołądka, trzustki, płuc, prostaty, tarczycy, nerek, jąder, jajników, szyjki macicy, tłuszczakomięsakach, glejakach i czerniaku skóry (HoJKA i RAPAK 2011, PETERS i współaut. 2012, YOUSEFI i współaut. 2016). Istnieja również doniesienia wskazujace na znacznie wyższa ekspresje PPARy w nowotworach nadnerczy i gruczolaku przysadki (WINCZYK 2008). Pomimo że rola PPARy w procesie nowotworzenia nadal nie jest jasno sprecyzowana, przeprowadzone badania przyczyniły się do powstania hipotezy, że gen kodujacy PPARy może pełnić funkcję genu supresorowego w procesie kancerogenezy, a jego mutacje sa czynnikiem sprzyjajacym powstawaniu nowotworu (WINCZYK 2008). Badania genetyczne wykazuja, że utrata nawet jednego $z$ alleli genu $P P A R Y$ zwiększa predyspozycje gryzoni do zachorowania na chorobę nowotworowa (TONTOZ i SpIEgELMAN 2008). Mutacje te sa jednak rzadko spotykane w komórkach nowotworowych ludzi, dlatego jednoznaczne określenie ich roli w kancerogenezie jest trudnym zadaniem. Należy zwrócić uwagę, że w przypadku pęcherzykowatego raka tarczycy zaobserwowano sprzyjajaca rozwojowi tego typu nowotworu aktywację PPARy. Stwierdzono aberrację chromosomowa, która polega na przeniesieniu fragmentu długiego ramienia 2. chromosomu kodującego $P A X 8$ (gen ważny w poczatkowych etapach rozwoju tarczycy) do krótkiego ramienia chromosomu 3., zawierajacego gen PPARY (SHAPAZ i współaut. 2015). Przeprowadzone badania potwierdzaja hipotezę, że gen fuzyjny $P A X 8 /$ PPARY (PPFP), powstały w wyniku tej translokacji, może pełnić rolę onkogenu w przypadku pęcherzykowatego raka tarczycy (RAMAN i KOENIG 2014). Inne badania wykazały, że aktywacja PPFP indukuje uruchomienie szlaku Wnt/TCF, który w komórkach tarczycy może powodować zmiany zwiększające inwazyjność nowotworu i jego wzrost niezależny od lokalizacji w organizmie (VU-PHAN i współaut. 2013). W przypadku innych schorzeń tarczycy, takich jak rak zróżnicowany tarczycy czy wole guzkowate, nie stwierdzono obecności PPFP. Wiele doniesień podkreśla wzmacniajacy kancerogenezę efekt mutacji $\mathrm{w}$ genie $P P A R Y$. U pacjentów $z$ rakiem jelita grubego odnotowuje się znacznie wyższa przeżywalność, kiedy ekspresja PPARy jest wykrywalna w tkance nowotworowej niż u pacjentów, u których nie stwierdzono ekspresji tego receptora (OGINO i współaut. 2009).

Większość opublikowanych do tej pory badań wykazuje, że aktywacja PPARy wywiera hamujacy wpływ na proces nowotworzenia (Ryc. 3), przede wszystkim poprzez indukcję apoptozy, działanie anty-proliferacyjne i zahamowanie procesu angiogenezy (PETERS i współaut. 2012). Innym ważnym powodem do przeprowadzenia badań dotyczacych określenia udziału PPARy w procesie kancerogenezy była dostępność ich ligandów o wysokim powinowactwie, które były już stosowane w leczeniu ludzi $z$ hiperlipidemia $i$ insulinoopornością. Tiazolidinediony (TZD), jako grupa agonistów PPARy, były wielokrotnie rozpatrywane jako czynniki w terapii przeciwnowotworowej. Na podstawie dostępnych wyników badań sugeruje się, że czynniki te, w połaczeniu $z$ innymi terapiami, moga wzmacniać działanie przeciwnowotworowe (FRÖHLICH i WAHL 2015). Wykazano, że pioglitazon ma duży wpływ na różnicowanie komórek ludzkiego tłuszczakomięsaka, w którym dochodzi do charakterystycznych zmian morfologicznych, zwiększonego gromadzenia lipidów w komórkach oraz do ekspresji białek, charakterystycznych dla zróżnicowanych komórek tkanki tłuszczowej (TONTOZ i SPIEGELMAN 2008). Przeprowadzono również badania kliniczne na kilku podtypach tłuszczakomięsaka $z$ użyciem troglitazonu. U niektórych pacjentów nie zaobserwowano żadnych efektów, jednak u kilku, z tłuszczakomięsakiem śluzowatym/okragłokomórkowym, nastapiło nagłe różnicowanie komórek guza i drastyczne zwiększenie wewnątrzkomórko- 


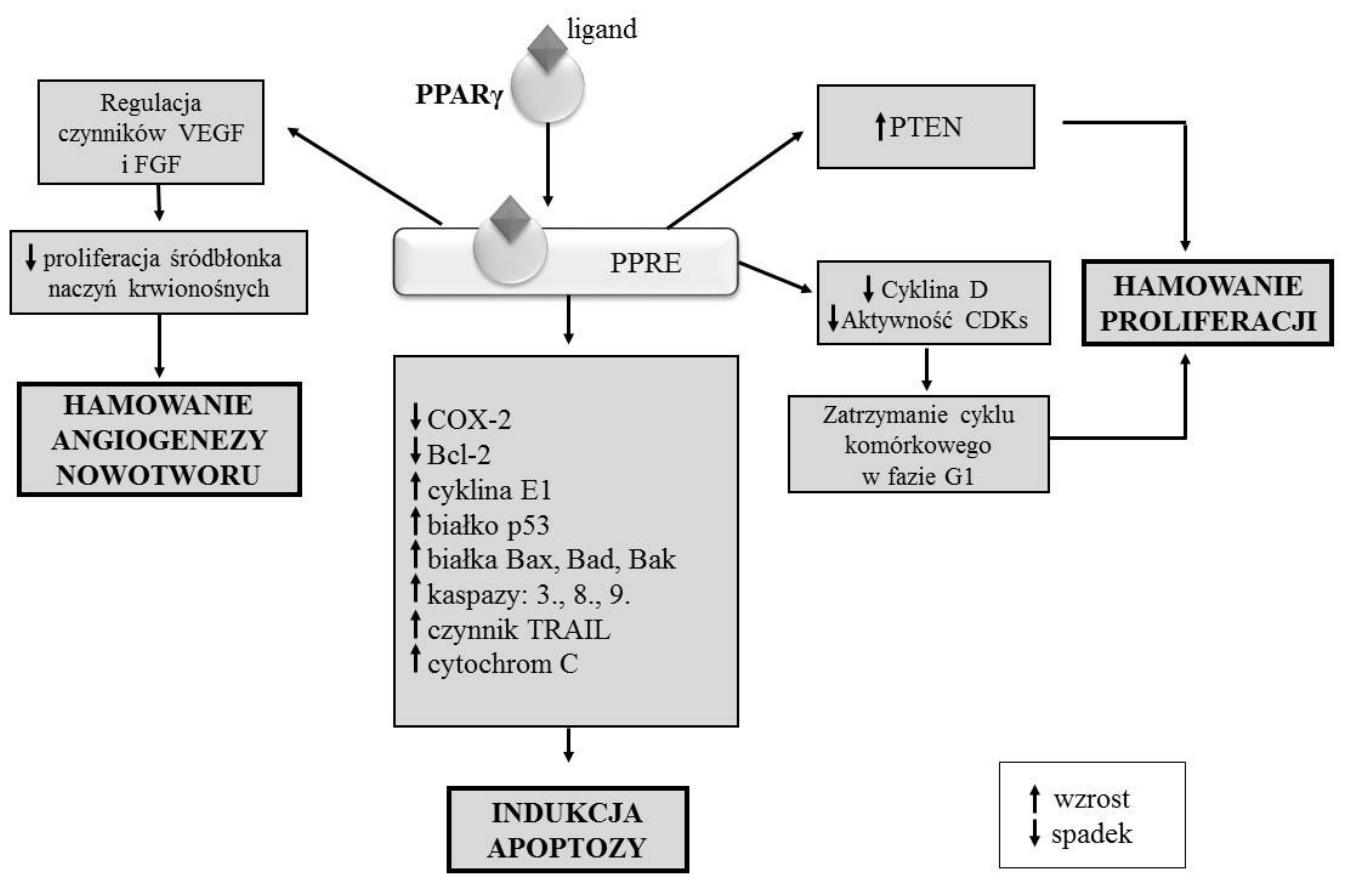

Ryc. 3. Schemat przedstawiający możliwe przeciwnowotworowe efekty aktywacji PPARy.

Bad - białko proapoptyczne $z$ podrodziny BH3-only, Bak - białko proapoptotyczne z rodziny Bcl-2, Bax - białko X łączące się z Bcl-2, CDKs - kinazy zależne od cyklin, COX-2 - cyklooksygenaza 2, FGF - czynnik wzrostu fibroblastów, PTEN - fosfataza fosfatydyloinozytolo-3,4,5-trifosforanu, TRAIL - ligand czynnika martwicy nowotworu indukujący apoptozę, VEGF - czynnik wzrostu śródbłonka naczyniowego, PPRE - element odpowiedzi na proliferatory peroksysomów.

wej akumulacji lipidów (DEMETRI i współaut. 1999). W przypadku nowotworu jajnika, inny agonista $z$ grupy TZD, ciglitazon, również hamował wzrost komórek. Podobne działanie, hamujace progresję nowotworu, wykazywał pioglitazon (BANNO i współaut. 2015). Dane wskazujace na anty-wzrostowe i pro-apoptotyczne efekty działania ligandów (zarówno agonistów, jak i antagonistów) PPARy otrzymano również w wielu innych komórkach nowotworowych, np. w komórkach raka jelita grubego (YANG i współaut. 2008), płuc (ZAVERI i współaut. 2009), tarczycy (WOOD i współaut. 2011), prostaty (AKINYEKE i STEWART 2011) czy pęcherza (WANG i współaut. 2016). Chociaż należy zachować ostrożność w założeniu, że wszystkie skutki leków TZD są wynikiem udziału PPARy, nie ma wątpliwości, że receptory te wykazuja potencjalny udział w modyfikowaniu tempa wzrostu wielu rodzajów komórek nowotworowych.

Aktywacja PPARy powiazana jest $z$ uruchomieniem wielu szlaków sygnalizacyjnych, których efekt często przeciwdziała rozwojowi nowotworu. Wykazano między innymi, że ligandy PPARy hamuja proliferację komórek linii raka prostaty i zmniejszaja ekspresję antygenu swoistego dla prostaty (PSA) (LEE i współaut. 2013). Hamowanie prolife- racji komórek przez PPARy może zachodzić w wyniku zwiększenia ekspresji genu PTEN (ang. phosphatase and tensin homolog) (KIM i współaut. 2015). Aktywacja tego supresorowego genu powoduje hamowanie proliferacji oraz zdolności migracyjnych komórek, co potwierdziły badania na nowotworach błony śluzowej macicy (NICKKHO-AMIRY i współaut. 2012), watroby (CAO i współaut. 2010), jelita grubego (ScHWAB i współaut. 2008), pęcherza moczowego (WANG i wsp. 2016) oraz płuc (HAN i ROMAN 2006). Zaproponowano także inny mechanizm hamowania proliferacji komórek nowotworowych. Podanie ligandów PPARy, takich jak troglitazon i roziglitazon, hamowało wzrost komórek w niektórych typach nowotworów poprzez zatrzymanie cyklu komórkowego w fazie G1, spowodowane zmniejszeniem stężenia cykliny D1, niezbędnej do wystapienia fazy S (TACHIBANA i współaut. 2008, YU i współaut. 2008). Istnieja również doniesienia, w których zaobserwowane zatrzymanie cyklu komórkowego w fazie G1 było skutkiem nie tylko obniżenia poziomu ekspresji cykliny D1, ale towarzyszył temu również spadek aktywności kinaz zależnych od cyklin (CDKs) (HoJKA i RAPAK 2011). Stwierdzono też, że aktywacja PPARy reguluje ekspresje białkowych inhibitorów CDKs, takich jak białka p21, p27 
czy p16. I tak na przykład, skutkiem zastosowania troglitazonu w przypadku komórek raka trzustki było zwiększenie ekspresji p27 (Motomura i współaut. 2000). Ten sam zwiazek spowodował wzrost ekspresji p21 w komórkach linii ludzkiego raka okrężnicy (Yousefi i współaut. 2016) oraz p21 i p16 w komórkach nowotworowych pęcherza moczowego (GUAN i współaut. 1999). W przypadku raka piersi, błony śluzowej macicy i tarczycy, dodatkowa droga oddziaływania jest interakcja szlaku sygnalizacyjnego receptorów estrogenowych, w szczególności receptora a (ERa), ze szlakiem sygnalizacyjnym PPARy (Yu i współaut. 2008). Zaobserwowano mianowicie, że troglitazon silniej hamuje wzrost komórek MCF-7 linii raka piersi dopiero po podaniu tamoxifenu, blokera receptora estrogenowego (Yu i współaut. 2008).

Wiele badań podkreśla znaczenie aktywacji PPARy w procesie apoptozy. Do tej pory potwierdzono pro-apototyczne działanie ligandów PPARy na komórki raka jelita grubego (YANG i FRUCHT 2001), piersi (COLIN-CASSIN i współaut. 2015), tarczycy (OHTA i współaut. 2001), trzustki (HAsHIMOTO i współaut. 2002), żołądka (HE i współaut. 2008), wątroby (CAO i współaut. 2010), gruczołu krokowego (AKINYEKE i STEWART 2011) i płuc (ZAVERI i współaut. 2009), a także na nowotwory wywodzace się $z$ układu nerwowego (WAN i współaut. 2011). Efekt ten związany jest ze stłumieniem ekspresji białka COX-2, obniżeniem syntezy białek $z$ rodziny Bcl i cykliny E1 oraz aktywacja białka supresorowego p53 (YOUSEFI i współaut. 2016). Indukcja programowanej śmierci komórki jest również następstwem zwiększenia ekspresji pro-apoptotycznych białek Bad, Bad, Bak, aktywacji kaspaz: 3., 8., 9. oraz liganda czynnika martwicy nowotworu indukującego apoptozę (TRAIL) oraz uwolnienia cytochromu C (HASHIMOTO i współaut. 2002, KIM i współaut. 2015). Podczas badań na komórkach nowotworu tarczycy zaobserwowano, że aktywacja PPARy powodowała zwiększenie skłonności do kondensacji jąder komórkowych oraz podziałów chromatyny na fragmenty. W komórkach raka tarczycy, w których nie obserwowano ekspresji PPARy taki efekt nie miał miejsca (OHTA i współaut. 2001).

Poza zwalczajacym nowotwór pro-apoptotycznym działaniem aktywowanego PPARy, istotna właściwościa jest również hamowanie angiogenezy, zarówno $\mathrm{w}$ badaniach in vitro, jak $\mathrm{i}$ in vivo (PETERs i współaut. 2012). Udowodniono, że tizolidinediony hamowały proliferacje i przyspieszały apoptoze komórek śródbłonka, działajac w sposób bezpośredni na śródbłonek naczyń (CAO i współaut. 2015). Podobny efekt obserwowano w ko- mórkach raka trzustki po podaniu agonistów PPARy, zarówno w warunkach in vitro, jak in vivo u myszy (DONG i współaut. 2009).W innych badaniach, przeprowadzonych na komórkach nowotworowych jajnika OVCAR-3 wykazano, że traktowanie komórek ciglitazonem (agonista PPAR $\gamma$ ) w połaczeniu $z$ cisplatina (lek stosowany w chemioterapii) skutkowało znacznym obniżeniem stopnia angiogenezy i wywoływało ich apoptozę (YoKOYAMA i współaut. 2011). TZD wykazywały również zdolność do hamowania angiogenezy w sposób pośredni, regulując ekspresje czynnika wzrostu śródbłonka naczyniowego (VEGF) oraz czynnika wzrostu fibroblastów (FGF) (ChintalgatTu i współaut. 2007). Ponadto wykazano, że aktywacja PPARy prowadzi do zahamowania aktywności metaloproteinaz MMP-2, MMP-7 i MMP-9, które często maja zwiazek $z$ dużą inwazyjnościa i stopniem zaawansowania nowotworu (SUNAMI i współaut. 2002, Grommes i współaut. 2006). Innym ważnym czynnikiem w nowotworzeniu jest oksydaza prolinowa (POX), która wchodzi w skład wewnętrznej błony mitochondrialnej oraz uczestniczy m.in. w oksydacji NADPH i transporcie elektronów. Wykazano nadekspresję tego enzymu w komórkach nowotworowych $\dot{i}$ stwierdzono, że czynnik ten reguluje ekspresję białka p53 (POLYAK i współaut. 1997) oraz inicjuje kaskadę prowadząca do apoptozy komórki (DONALD i współaut. 2001). PANDHARE i współaut. (2006) udowodnili, że troglitazon może aktywować promotor genu $P O X \mathrm{w}$ komórkach $\mathrm{HCT} 15$ raka jelita grubego i tym samym uczestniczy w indukowaniu apoptozy (PANDHARE i współaut. 2006). Podobne wyniki uzyskano przy użyciu innego agonisty, roziglitazonu, badajacc komórki raka płuc (KIM i współaut. 2007).

\section{PODSUMOWANIE}

$\mathrm{Na}$ podstawie przedstawionych wyników badań można stwierdzić istotne znaczenie PPARa w patofizjologii chorób nowotworowych. Aktywacja tego receptora w komórkach watroby gryzoni skutkuje wywołaniem stresu oksydacyjnego, którego konsekwencja jest uszkodzenie DNA i, w efekcie, nadmierna proliferacja komórek. Uważa się, że ten proces jest jednym $z$ najważniejszych elementów odpowiedzialnych za transformacje nowotworowa spowodowana aktywacja PPARa. Aktywacja PPARa nie powoduje rozwoju nowotworu u ludzi, a przyczyna gatunkowo-specyficznych różnic może być niewspółmiernie wysoki poziom ekspresji tej izoformy receptora w watrobie gryzoni, w porównaniu $z$ watroba ludzka. Informacje na temat udziału izoformy PPAR $\beta / \delta \mathrm{w}$ procesie nowotworzenia sa mało spójne. Wyni- 
ki badań wskazuja zarówno na pro-, jak i antynowotworowe działanie tej formy receptora. Sprzeczności w literaturze dotycza nie tylko funkcji receptora PPAR $\beta / \delta \mathrm{w}$ procesie kancerogenezy, ale i udziału towarzyszacych szlaków sygnalizacyjnych. Szereg doniesień wskazuje na istotne znaczenie receptora PPARy w procesie kancerogenezy. Izoforma ta może pełnić rolę genu supresorowego, a zaburzenia w jego prawidłowej ekspresji zwiększaja ryzyko powstania nowotworu. Aktywacja PPARy za pomoca ligandów $z$ grupy TZD przynosiła oczekiwane rezultaty $\mathrm{w}$ postaci hamowania proliferacji komórek nowotworowych i angiogenezy oraz indukowania apoptozy. Potwierdzeniem tych efektów sa również badania, w których podawanie antagonistów PPARy blokowało aktywność receptora $\mathrm{i}$ w rezultacie prowadziło do progresji nowotworów.

Efekty tych badań świadczą o istnieniu zależności pomiędzy działaniem PPAR i ich ligandów a procesem nowotworzenia, jednak ich rola wydaje się bardzo złożona i pozostaje nadal niejednoznaczna. Dużym wyzwaniem dla naukowców jest dokładne poznanie molekularnych mechanizmów działania agonistów PPAR w różnych tkankach i typach nowotworów, które sa prawdopodobnie zależne również od innych czynników. Mimo tego, badania $z$ wykorzystaniem różnych ligandów PPAR mogą okazać się bardzo istotne w poszukiwaniu przyczyn chorób nowotworowych oraz nowych terapeutycznych strategii podczas prewencji i leczenia niektórych typów nowotworów.

\section{Streszczenie}

Receptory aktywowane przez proliferatory peroksysomów (PPAR) należą do rodziny receptorów jądrowych. Dotychczas scharakteryzowano ich trzy izoformy: alfa, beta i gamma, które jako ligando-zależne czynniki transkrypcyjne zaangażowane sa $\mathrm{w}$ regulację różnych procesów fizjologicznych $\mathrm{w}$ organizmie. Ich podstawowa funkcja jest udział w metabolizmie lipidów i glukozy. PPAR uczestniczą również $\mathrm{w}$ reakcji zapalnej oraz $\mathrm{w}$ kontroli proliferacji i różnicowania komórek, a także w regulowaniu procesów rozrodczych. Wyniki wielu badań wskazuja, że receptory te zaangażowane sa $\mathrm{w}$ proces nowotworzenia, chociaż rola poszczególnych izoform nie jest jednoznacznie zdefiniowana. Izoforma alfa uczestniczy w powstawaniu raka watrobowokomórkowego u gryzoni, jednak $\mathrm{w}$ przypadku ludzkich hepatocytów długotrwała aktywacja tej izoformy nie wywołuje zmian nowotworowych. Udział PPAR $\beta / \delta \mathrm{w}$ procesie kancerogenezy jest najbardziej niesprecyzowany spośród wszystkich izoform PPAR. Istnieja przypuszczenia, że pełni ona ważna rolę w powstawaniu raka jelita grubego. $Z$ kolei, ekspresje PPARy obserwuje się w wielu typach komórek nowotworowych, a rola tej izoformy w powstawaniu nowotworów jest najbardziej złożona. Wykazuje ona $\mathrm{m}$. in. właściwości anty-proliferacyjne i proapoptotyczne, hamuje angiogenezę oraz indukuje końcowe różnicowanie komórek. W niniejszej pracy przedstawiono istniejace poglądy i kontrowersje na temat udziału trzech izoform PPAR w procesie nowotworzenia.

\section{LITERATURA}

Abu Aboud O., Donohoe D., Bultman S., Fitch M., RIIFF T., HEllerstein M., WeISS R. H., 2015. PPARa inhibition modulates multiple reprogrammed metabolic pathways in kidney cancer and attenuates tumor growth. Am. J. Physiol. Cell Physiol. 308, C890-C898.

AKInYeKe T. O., SteWART L. V., 2011. Troglitazone suppresses c-Myc levels in human prostate cancer cells via a PPARY-independent mechanizm. Cancer Biol. Ther. 11, 1046-1058.

BanNo K., IIDA M., YANOKURA M., IRIE H., MASUdA K., Kobayashi Y., TOMinaga E., AOKI D., 2015. Drug respositioning for gynecologic tumors: a new therapeutic strategy of cancer. Sci. World J., doi: 10.1155/2015/341362.

BenedetTi E., D’Angelo M., Ammazzalorso A., GRavina G. L., LAEZzA C., ANTONOSANTE A., Panella G., Cinque B., CRistiano L., Dhez A.C., Astarita C., Galzio R., Cifone M. G., IPPOLITI R., AMOROSO R., Di CESARE E., GIORDANO A., CIMINI A., 2016. PPARa antagonist AA452 triggers metabolic reprogramming and increases sensitivity to radiation therapy in human glioblastoma primary cells. J. Cell Physiol. 13, doi: 10.1002/jcp.25648.

Bieri F., Bentley P., WAechter F., StäUbli W., 1984. Use of primary cultures of adult rat hepatocytes to investigate mechanisms of action of nafenopin, a hepatocarcinogenic peroxisome proliferator. Carcinogenesis 5, 1033-1039.

BOGACKA I., KURZYŃSKA A., BOGACKI M., CHOJNOWSKA K., 2015. Peroxisome proliferator-activated receptors in the regulation of female reproductive functions. Folia Histochem. Cytobiol. 53, 189-200.

CAO L. Q., SHAO Z. L., Liang H. H., Zhang D. W., YANG X. W., JiAnG X. F., XUE P., 2015. Activation of peroxisome proliferator-activated receptor-y (PPARY) inhibits hepatoma cell growth via downregulation of SEPT2 expression. Cancer Lett. 359, 127-135.

CaO L. Q., ShaO Z. L., Peng H. P., Xiao J. B., XIA T., 2010. Rosiglitazone enhances 5-fluorouracil-induced cell growth inhibition in hepatocellular carcinoma cell line Hep3B. Chin. J. Cancer. 29, 741-746.

Chan G., BOYle J. O., YANG E. K., Zhang F., SACKS P. G., SHAH J. P., EDELSTEIN D., SOSLOW R. A., KOKI A. T., WOERNER B. M., MASFERRER J. L., DANNENBERG A. J., 1999. Cyclooksygenase-2 expression is up-regulated in squamous cell carcinoma of the head and neck. Cancer Res. 59, 991-994.

ChintalgatTu V., Harris G. S., AKula S. M., KatWA L. C., 2007. PPAR-gamma agonists induce the expression of VEGF and its receptors in cultured cardiac myofibroblasts. Cardiovasc. Res. 74, 140-150.

Chittiboyina A. G., Venkatraman M. S., Mizuno C. S., Desai P. V., Patny A., Benson S. C., Ho C. I., Kurtz T. W., PERShadsingh H. A., AVERY M. A., 2006. Design and synthesis of the first generation of dithiolane thiazolidinedione- and phenylacetic acid-based PPAR gamma agonists. J. Med. Chem. 49, 4072-4084.

COLIN-CASSIN C., YAO X., CERELla C., CHBICHEB S., Kuntz S., MAZERBourg S., BoISBurn M., CHAPLEUR Y., DIEDERICH M., Flament S., GRILLIER-VUISSOZ I., 2015. PPARY-inactive $\triangle 2$ troglitazone independently triggers ER stress and apoptosis in breast cancer cells. Mol. Carcinog. 54, 393-404.

DAY C., 1999. Thiazolidinediones: a new class of antidiabetic drugs. Diabet. Med. 16, 179-192. 
Demetri G. D., Fletcher C. D. M., Mueller E., SARRAF P., NAUJOKS R., CAMPBELL N., SPIEGELMAN B. M., SINGER S., 1999. Induction of solid tumor differentation by the peroxisome proliferator-activated receptor- $\gamma$ ligand troglitazone in patients with liposarcoma. Proc. Natl. Acad. Sci. USA. 96, 3951-3956.

Donald S. P., Sun X. Y., Hu C. A., Yu J., Mei J. M., Valle D., Phang J. M., 2001. Proline oxidase, encoded by p53-induced gene-6, catalyzes the generation of proline-dependent reactive oxygen species. Cancer Res. 1, 1810-1815.

DONG Y. W., WANG X. P., WU K., 2009. Suppression of pancreatic carcinoma growth by activating peroxisome proliferator-activated receptor gamma involves angiogenesis inhibition. World J. Gastroenterol. 15, 441-448.

Fajas L., Auboeuf D., Raspé E., Schoonjans K., Lefebvre A. M., SAladin R., NAJIB J., LaVILle M., Fruchart J. C., DEEB S., VidAl-Puig A., Flier J., BRiggs M. R., Staels B., Vidal H. i wspólaut., 1997. The organization, promoter analysis, and expression of the human PPARY gene. J. Biol. Chem. 272, 18779-18789.

Forman B. M., CHEN J., Evans R. M., 1997. Hypolipidemic drugs, polyunsaturated fatty acids, and eicosanoids are ligands for peroxisome proliferator-activated receptors alpha and delta. Proc. Natl. Acad. Sci. USA. 94, 43124317.

FrEeman S. R., DRAKE A. L., HEILIG L. F., GRaber M., McNealy K., Schilling L. M., Dellavalle R. P., 2006. Statins, fibrates, and melanoma risk: a systematic review and meta-analysis. J. Natl. Cancer Inst. 98, 1538-1546.

FRÖHLICH E., WAHL R., 2015. Chemotherapy and chemoprevention by thiazolidinediones. Biomed. Res. Int., 10.1155/2015/845340.

GARDETTE V., BONGARD V., DALLONGEVILlE J., ARVEIlER D., BINGHAM A., RuIDAVETS J. B., AMOUYEl P., HAAS B., DUCIMETIÉRE P., FERRIÉRES J., 2009.Ten-year all-cause mortality in preusmably health subjects on lipid-lowering drugs (from the Prospective Epidemiological Study of Myocardial Infarction [PRIME] prospective cohort). Am. J. Cardiol. 103, 381386.

Giometti C. S., Liang X., Tollaksen S. L., Wall D. B., Lubman D. M., SubbaraO V., RaO M. S., 2000. Mouse liver selenium-binding protein decreased in abundance by peroxisome proliferators. Electrophoresis. 21, 2162-2169.

GROMMES C., LANDRETH G. E., SASTRE M., BECK M., Feinstein D. L., Jacobs A. H., SchleGEL U., HENEKA M. T., 2006. Inhibition of in vivo glioma growth and invasion by peroxisome proliferator-activated receptor gamma agonist treatment. Mol. Pharmacol. 70, 1524-1533.

GUAN Y. F., ZHANG Y. H., BREYER R. M., DAVIS L., BREYER M. D., 1999. Expression of peroxisome proliferator-activated receptor Y (PPARY) in human transitional bladder cancer and its role in inducing cell death. Neoplasia 1, 330339.

GuPTA R. A., DuBois R. N., 2001. Colorectal cancer prevention and treatment by inhibition of cyclooxygenase-2. Nat. Rev. Cancer. 1, 11-21.

Gupta R. A., TAN J., KRAUSE W. F., GERACI W. W., Willson T. M., DEY S. K., DuBoIs R. N., 2000. Prostacyclin-mediated activation of peroxisome proliferator-activated receptor delta in colorectal cancer. Proc. Natl. Acad. Sci. USA. 97, 13275-13280.

HAN S., ROMAN J., 2006. Rosiglitazone suppresses human lung carcinoma cell growth through PPAR gamma-dependent and PPAR gamma-in- dependent signal pathways. Mol. Cancer. Ther. 5, 430-437.

HasegaWA K., OHASHI Y., IshiKaWA K., Yasue A., KATO R., ACHIWA Y., NiSHIO E., UdAGAWA Y., 2005. Expression of cyclooxygenase-2 in uterine endometrial cancer and anti-tumor effects of a selective COX-2 inhibitor. Int. J. Oncol. 26, 1419-1428.

HASHIMOTO K., ETHRIDGE R. T., Evers B. M. 2002. Peroxisome proliferator-activated receptor gamma ligand inhibits cell growth and invasion of human pancreatic cancer cells. Int. J. Gastrointest. Cancer. 32, 7-22.

Hays T., Rusyn I., BuRns A. M., KennetT M. J., WARD J. M., GonZalez F. J., Peters J. M., 2005. Role of peroxisome proliferator-activated receptor-alpha (PPAR aplha) in bezafibrate-induced hepatocarcinogenesis and cholestasis. Carcinogenesis. 26, 219-227.

HE Q., PANG R., SONG X., CHEN J., CHEN H., CHEN B., Hu P., CHEN M., 2008. Rosiglitazone suppresses the growth and invasiveness od SGC-7901 gastric cancer cells and angiogenesis in vitro via PPAR gamma dependent and independent mechanisms. PPAR Res., $10.1155 / 2008 / 649808$

He T. C., Chan T. A., Vogelstein B., Kinzler K. W., 1999. PPARS is an APC-regulated target of nonsteroidal anti-inflammatory drugs. Cell 99, 335-345.

Hida T., YataBE Y., ACHiWA H., Muramatsu H., KOZAKI K., NAKAMURA S., OGAWA M., MitSUDOMI T., Sugiura T., TAKAHASHI T., 1998. Increased expression of cyclooxygenase 2 occurs frequently in human lung cancers, specifically in adenocarcinomas. Cancer Res. 58, 37613764.

HOJKA A., RAPAK A., 2011. Receptory aktywowane proliferatorami peroksysomów (PPAR). Właściwości anty-proliferacyjne. Post. Hig. Med. Dosw. 65, 404-413.

ISSEMAN I., GREEN S., 1990. Activation of a member of the steroid hormone receptor superfamily by peroxisome proliferators. Nature 347, 645-650.

KASAI H., OKADA Y., NISHIMURA S., RAO M. S., REDDY J. K., 1989. Formation of 8-hydroksydeoxyguanosine in liver DNA of rats following long-term exposure to a peroxisome proliferator. Cancer Res.49, 2603-2605.

KIM J., SONG J., PARK K. W., 2015. The multifaceted factor peroxisome proliferator-activated receptor $\gamma(P P A R \gamma)$ in metabolism, immunity and cancer. Arch. Pharm. Res. 38, 302-312.

Kim K. Y., AHN J. H., CHEON H. G., 2007. Apoptotic action of peroxisome proliferator-activated receptor-gamma activation in human non-small-cell lung cancer is mediated via proline oxidase-induced reactive oxygen species formation. Mol. Pharmacol. 72, 674-685.

KREY G., BRAissant O., L'HorSET F., KalKhOVEN E., PERRoud M., PARKER M.G., WAHLI W. 1997. Fatty acids, eicosanoids, and hypolipidemic agents indetified as ligands of peroxisome proliferator-activated receptors by coactivator-dependent receptor ligand assay. Mol. Endocrinol. 11, 779-791.

LeE N. J., OH J. H., BAN J. O., Shim J. H., LeE H. P., Jung J. K., AhN B. W., YoON D. Y., HAN S. B., HAM Y. W., HONG J. T., 2013. 4-O-methylhonokiol, a PPARY agonist, inhibits prostate tumor growth: p21-mediated suppression of $N F-k B$ activity. Br. J. Pharmacol. 168, 1133-1145.

MisRA P., REDDY J. K., 2014. Peroxisome proliferator-activated receptor-a activation and excess 
energy burning in hepatocarcinogenesis. Biochimie. 98, 63-74.

MOTOMURA W., OKUMURA T., TAKAHASHI N., OBARA T., KoHgo Y., 2000. Activation of peroxisome proliferator-activated receptor $\mathrm{\gamma}$ by troglitazone inhibits cell growth through the increase of p27kip 1 in human pancreatic carcinoma cells. Cancer Res. 60, 5558-5564.

MRÓWKA M., GŁODKOWSKA-MRÓWKA E., 2011. Struktura, działanie $i$ rola receptora-gamma peroksysomów aktywowanego przez proliferatory - PPARY. Post. Biol. Kom. 38, 629-652.

MÜLLER R. 2016. PPARß/ס in human cancer. Biochimie. 2, pii: S0300-9084(16)30193-6.

NickKHO-AMiRY M., McVeY R., Holland C., 2012. Peroxisome proliferator-activated receptors modulate proliferation and angiogenesis in human endometrial carcinoma. Mol. Cancer. Res.10, 441-453.

OGinO S., SHIMA K., BABA Y., NOSHO K., IRAHARA N., KURE S., CHEN L., TOYODA S., KIRKNER G. J., WANG Y. L., GIOVANNUCCI E. L., FUCHS C. S., 2009. Colorectal cancer expression of peroxisome proliferator-activated receptor gamma (PPARG, PPAR gamma) is associated with good prognosis. Gastroenterology 136, 12421250.

OHTA K., ENDO T., HARAgUChI K., HERshman J. M., ONAYA T., 2001. Ligands for peroxisome proliferator-activated receptor gamma inhibit growth and induce apoptosis of human papillary thyroid carcinoma cells. J. Clin. Endocrinol. Metab. 86, 2170-2177.

Oliver W. R., SHENK J. L., SNAith M. R., Russell C. S., Plunket K. D., Bodkin N. L., Lewis M. C., Winegar D. A., Sznaidman M. L., LAMBert M. H., Xu H. E., Sternbach D. D., Kliewer S. A., Hansen B. C., Wilson T. M., 2001. A selective peroxisome proliferator-activated receptor delta agonist promotes reverse cholesterol transport. Proc. Natl. Acad. Sci. USA. 98, 5306-5311.

Palmer C. N., Hsu M. H., Griffin K. J., Raucy J. L., JoHnson E. F., 1998. Peroxisome proliferator-activated receptor-a expression in human liver. Mol. Pharmacol. 53, 14-22.

PANDhARE J., COOPER S. K., PHANG J. M., 2006. Proline oxidase, a proapoptotic gene, is induced by troglitazone: evidence for both peroxisome proliferator-activated receptor gamma -dependent and -independent mechanisms. J. Biol. Chem. 281, 2044-52.

Peters J. M., Cattley R. C., Gonzalez F. J., 1997. Role of PPAR Ralpha in the mechanism of action of the nongenotoxic carcinogen and peroxisome proliferator Wy-14,643. Carcinogenesis 18, 2029-2033.

PETERS J. M., SHAH Y. M., GonZAlez F. J., 2012. The role of peroxisome proliferator-activated receptors in carcinogenesis and chemoprevention. Nat. Rev. Cancer. 12, 181-195.

Peters J. M., Gonzales F. J., MÜlleR R., 2015. Establishing the role of $P P A R \beta / \delta$ in carcinogenesis. Trends Endocrinol. Metabol. 26, 595-607.

POLYAK K., XIA Y., ZWEIER J. L., KINZLER K. W., VOGELSTEIN B., 1997. A model for p53-induced apoptosis. Nature 389, 300-305.

RAMAN P., KOENIG R. J., 2014. PAX8-PPARY fusion protein in thyroid carcinoma. Nat. Rev. Endocrinol. 10, 616-623.

SAIDI S. A., Holland C. M., CHARNOCK-Jones D. S., SMITH S. K., 2006. In vitro and in vivo effects of the PPARa agonists fenofibrate and retinoic acid in endometrial cancer. Mol. Cancer. $5,13$.
SAlvo F., Bazin F., RoBinson P., MOORE N. D., 2014. Fibrates and risk of cancer in tissues with high PPAR-a concentration: A nested case-control study. Drug Saf. 37, 361-368.

Schoojans K., Watanabe M., Suzuki H., MahfouDI A., KREY G., WAHLI W., GRIMALDI P., STAEIS B., YAMAMOTO T., AUWERX J., 1995. Induction of the acyl-coenzyme A synthetase gene by $f$ brates and fatty acids in mediated by a peroxisome proliferator response element in the $C$ promoter. J. Biol. Chem. 270, 19269-19276.

SCHWAB M., REYNDERS V., LOITSCH S., SHASTRI Y. M., STEINHILBER D., SCHRÖDER O., STEIN J., 2008. PPARgamma is involved in mesalazine-mediated induction of apoptosis and inhibition of cell growth in colon cancer cells. Carcinogenesis 29, 1407-1414.

SHaH Y. M., MoRimura K., Yang Q., TANaBe T., TAKagi M., Gonzalez F. J., 2007. Peroxisome proliferator-activated receptor alpha regulates a microRNA-mediated signaling cascade responsible for hepatocellular proliferation. Mol. Cell. Biol. 27, 4238-4247.

Shapaz A., ÖNAL B., Yesilyurt A., HaN Ü., DelIBASI T., 2015. BRAF(V6OOE) mutation, RET/ PTC1 and PAX8-PPAR gamma rearrangements in follicular epithelium derived thyroid lesions - institutional experience and literature review. Balkan Med. J. 32, 156-166.

SHUREIQI I., JiANG W., ZUO X., WU Y., STIMMEL J. B., LEESNITZER L. M., MORRIS J. S., FAN H., Fischer S. M., LIPPMAN S. M., 2003. The 15-lipooxygenase-1 product 13-S-hydroxyoctadecadienoic acid down-regulates PPAR- $\delta$ to induce apoptosis in colorectal cancer cells. Proc. Natl. Acad. Sci. USA. 100, 9968-9973.

Soslow R. A., DANnEnBerg A. J., Rush D., WoERNER B. M., KHAN K. N., MASFERRER J., KOKI A. T., 2000.COX-2 is expressed in human pulmonary, colonic, and mammary tumors. Cancer 89, 2637-2645.

STRAKOVA N., EHRMANN J., BARTOS J., MALIKOVA J., Dolezel J., KolaR Z., 2005. Peroxisome proliferator-activated receptors (PPAR) agonists affect cell viability, apoptosis and expression of cell cycle related proteins in cell lines of glial brain tumors. Neoplasma 52, 126-136.

Sunami E., Tsuno N. H., Kitayama J., SAITO S., OSAda T., Yamaguchi H., TOMOzaWA S., TSURUO T., SHIBATA Y., NAGAWA H., 2002. Decreased synthesis of matrix metalloproteinase-7 and adhesion to the extracellular matrix proteins of human colon cancer cells treated with troglitazone. Surg. Today. 32, 343-350.

TACHIBANA K., YAMASAKI D., ISHIMOTO K., DOI T. 2008. The role of PPARs in cancer. PPAR Res., doi:10.1155/2008/102.

TONTOZ P., SPIEGELMAN B. M., 2008. Fat and Beyond: The diverse biology of PPARy. Ann. Rev. Biochem. 77, 289-312.

TUCKER O. N., DANNENBERG A. J., YANG E. K., Zhang F., Teng L., Daly J. M., SOSlOW R. A., Masferrer J. L., Woerner B. M., KoKI A. T., FAHEY T. J., 1999. Cyclooxygenase-2 expression is up -regulated in human pancreatic cancer. Cancer Res. 59, 987-990.

Vu-PhAN D., GRACHTCHOUK V., Yu J., COlBy L. A., WichA M. S., KOENIG R. J., 2013. The thyroid cancer PAX8-PPARG fusion protein activates Wnt/TCF-responsive cells that have a transformer phenotype. Endocr. Relat. Cancer 20, 725-739.

Wan Z., ShI W., ShaO B., ShI J., Shen A., MA Y., CHEN J., LAN Q., 2011. Peroxisome proliferator-activated receptor $\mathrm{Y}$ agonist pioglitazone 
inhibits $\beta$-catenin-mediated glioma cell growth and invasion. Mol. Cell. Biochem. 349, 1-10.

WANG G., CAO R., WANG Y., QIAN G., DAN H.C., JiANG W., JU L., WU M., XIAO Y., WANG X., 2016. Simvastatin induces cell cycle arrest and inhibits proliferation of bladder cancer cells via PPARY signalling pathway. Sci Rep. $25,35783$.

Willson T. M., BRown P. J., STRENBACH D. D., HENKE B. R., 2000. The PPARs: from orphan receptors to drug discovery. J. Med. Chem. 43, 527-550.

WINCZYK K., 2008. Znaczenie receptorów gamma aktywowanych proliferatorami peroksysomów (PPARY) $w$ nowotworach gruczołów dokrew nych. Endokrynol. Pol. 59, 156-166.

Wood W. M., SHARMA V., BAUERle K. T., Pike L. A., Zhou Q., Fretwell D. L., SChwePPE R. E., HaUgen B. P., 2011. PPARy promotes growth and invasion of thyroid cancer cells. PPAR Res., doi:10.1155/2011/171765.

Wu T. T., NIU H. S., CHEN L. J., CHENG J. T., TONG Y. C., 2016. Increase of human prostate cancer cell (DU145) apoptosis by telmisartan through PPAR-delta pathway. Eur. J. Pharmacol. $775,35-42$.

YANG L., Zhang H., Zhou Z. G., YaN H., Adell G., SUN X. F., 2011. Biological function and prognostic significance of peroxisome proliferator-activated receptor $\delta$ in rectal cancer. Clin. Cancer Res. 17, 3760-3770.

Yang Q., Nagano T., Shah Y., Cheung C., Ito S., GONZALEZ F. J., 2008. The PPARa-humanized mouse: a model to investigate species differences in liver toxicity Mediatel by PPARa. Toxicol. Sci. 101, 132-139.

YANG W. L., FRUCHT H., 2001. Activation of the PPAR pathway induces apoptosis and COX-2 inhibition in HT-29 human colon cancer cells. Carcinogenesis 22, 1379-1383.

Yokoyama Y., Xin B., Shigeto T., Mizunuma H., 2011. Combination of ciglitazone, a peroxi- some proliferator-activated receptor gamma ligand, and cisplatin enhances the inhibition of growth of human ovarian cancers. J. Cancer Res. Clin. Oncol. 137, 1219-1228.

Yokoyama Y., Xin B., Shigeto T., Umemoto M., KASAI-SAKAMOTO A., FUTAGAMI M., TSUCHIDA S., Al-Mulla F., Mizunuma H., 2007. Clofibric acid, a peroxisome proliferator-activated receptor alpha ligand, inhibits growth of human ovarian cancer. Mol. Cancer Ther. 6, 13791386.

YOSHINAGA M., KITAMURA Y., CHAEN T., YAMASHITA S., Tsuruta S., Hisano T., IKeda Y., SAKaI H., NAKAMURA K., TAKAYANAGI R., MUTO Y., 2009. The simultaneous expression of peroxisome proliferator-activated receptor delta and cyklooxygenase-2 may enhance angiogenesis and tumor venous invasion in tissues of colorectal cancers. Dig. Dis. Sci. 54, 1108-1114.

YOUSEFI B., SAMADI N., BARADARAN B., SHAFIEI-IRANNEJAD V., ZARGHAMI N., 2016. Peroxisome proliferator-activated receptor ligands and their role in chronic myeloid leucemia: therapeutic strategies. Chem. Biol. Drug Des. 88, 17-25.

Yu H. N., LEe Y. R., NOH E. M., LeE K. S., KIM J. S., Song E. K., HaN M. K., LeE Y. C., KWON K. B., LEE S. J., Youn H. J., JUNG S. $\mathrm{H}$., 2008. Induction of G1 phase arrest and apoptosis in MDA-MB-231 breast cancer cells by troglitazone, a synthetic peroxisome proliferator-activated receptor gamma (PPAR gamma) ligand. Cell Biol. Int. 32, 906-912.

Zaveri N. T., SATO B. G., Jiang F., CalaoAgan J., Laderoute K. R., Murphy B. J., 2009. A novel peroxisome proliferator-activated receptor delta antagonist, SR13904, Has anti-proliferative activity in human cancer cells. Cancer Biol. Ther. 8, 1252-1261. 
KOSMOS Vol. 67, 2, 361-373, 2018

Anna SzydŁowska, Aleksandra Kurzyńska, Zuzanna Kunicka, Iwona Bogacka

Department of Animal Anatomy and Physiology, Faculty of Biology and Biotechnology, University of Warmia and Mazury in Olsztyn, 1A Oczapowskiego Str., 10-718 Olsztyn,E-mail: iwonab@uwm.edu.pl

PEROXISOME PROLIFERATOR-ACTIVATED RECEPTORS IN CARCINOGENESIS - FACTS AND CONTROVERSIES

Summary

Peroxisome proliferator-activated receptors (PPARs) belong to the nuclear receptor family. So far, three isoforms of PPARs: alpha, beta and gamma have been described. As ligand-dependent transcription factors, they participate in the regulation of diverse physiological processes. PPARs are involved in the regulation of lipid and glucose metabolism. They also control inflammatory processes or cell proliferation and differentiation. PPARs are also implicated in the regulation of reproductive functions. Furthermore, results of several studies clearly indicate, that PPARs are involved in carcinogenesis. PPARa mediates in hepatocellular tumor growth in rodents, but its role in human hepatocytes is not so obvious as in rodents. The role of PPAR $\beta / \delta$ in carcinogenesis still remains unclear. It is believed, that PPAR $\beta / \delta$ has important function in colorectal tumor growth. In turn, the expression of PPAR $\gamma$ has been demonstrated in different types of tumor cells and its role in carcinogenesis seems the most complex. There are reports that indicate antiproliferative and proapoptotic effects of PPARy activation. It has been also demonstrated that PPARY ligands inhibit angiogenesis and induce terminal differentiation. In this review, we summarize current findings regarding the involvement of the three PPAR isoforms in carcinogenesis.

Key words: cancer, carcinogenesis, nuclear receptors, PPAR ligands, transcription factors 